\title{
The challenges of consolidation of a Drought- Related Disaster Risk Warning System to Brazil
}

\author{
Desafios para a consolidação de um Sistema de Alerta de Risco de Desastre \\ Associado às Secas no Brasil
}

\author{
Ana Paula Martins do Amaral Cunha ${ }^{a}$ \\ Victor Marchezini ${ }^{b}$ \\ Diego Pereira Lindosoc \\ Silvia Midori Saito ${ }^{d}$ \\ Regina Célia dos Santos Alvaláe
}

${ }^{a}$ Researcher at Cemaden, São José dos Campos, SP. Brazil. Email: ana.cunha@cemaden.gov.br

${ }^{b}$ Researcher at Cemaden, Professor at Earth System Science Center, National Space Research Institute (INPE) (PGCST/INPE). São José dos Campos, SP. Brazil. Email: victor.marchezini@cemaden.gov.br

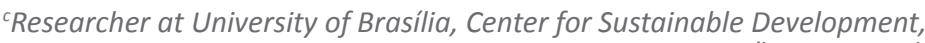
Brasília, DF, Brazil. End. Eletrônico: diegoplindoso@gmail.com

${ }^{d}$ Researcher at Cemaden, São José dos Campos, SP, Brazil. End. Eletrônico: silvia.saito@cemaden.gov.br

${ }^{e}$ Researcher at Cemaden, São José dos Campos, SP, Brazil. Email: regina.alvala@cemaden.gov.br

doi:10.18472/SustDeb.v10n1.2019.19380

Received: 11/20/2018

Accepted:04/08/2019

ARTICLE - VARIA

\begin{abstract}
In Brazil, droughts are widespread and recurrent in the semiarid region, mainly due to its water vulnerability. Approximately 28 million people live in the region, which concentrates the highest proportion of people living in poverty in Brazil. If drought occurs intensively and extensively in densely populated areas, it can result in disaster when local capacities are insufficient to avoid significant damage. The risks associated with drought are related to the natural hazard, local vulnerabilities, response capacity, and mitigation policies. This study presents the challenges for the consolidation of a drought risk warning system in Brazil and proposes an initial structure for assigning responsibilities among the national institutions involved in the theme in order to guide actions for the risk mitigation.
\end{abstract}

Keywords: Drought Risk; Drought Monitoring; Semiarid; Vulnerability.

\section{RESUMO}

No Brasil, a seca é um fenômeno caracterizado pela sua ampla cobertura espacial e recorrência na região semiárida, principalmente devido à sua vulnerabilidade hídrica. Quase 28 milhões de pessoas vivem na região, que concentra a maior parte da população mais pobre do Brasil. Assim, a seca é uma ameaça 
natural à medida que ocorre de forma intensiva e extensiva em áreas densamente povoadas, podendo resultar em desastre quando as capacidades locais são insuficientes para evitar danos significativos. $O$ risco de um desastre à seca está relacionado com a ameaça física, as vulnerabilidades locais, a capacidade de resposta e com as políticas de mitigação. O presente estudo apresenta os desafios para a consolidação de um sistema de alerta de risco de desastres associados às secas no Brasil e propõe uma estrutura inicial de atribuição de responsabilidades entre as instituições nacionais envolvidas com a temática com a finalidade de guiar ações para a mitigação dos riscos.

Palavras-chave: Risco de seca; Monitoramento de seca; Semiárido; Vulnerabilidade.

\section{INTRODUCTION}

Drought is a natural phenomenon that is recurrent in several regions of the globe. It is generally characterized as a natural hazard if it occurs intensively and extensively in densely populated areas and can result in disaster when local capacities are insufficient to avoid significant damage (material and human) and losses (socioeconomic). In an area prone to drought, the vulnerability of the local people and social groups differs, as do the resources they have to deal with situations or long periods of drought and prevent damage and loss from a disaster. Disaster risk is associated with the relationship between a hazard, vulnerabilities, responsiveness, and mitigation policies.

In Brazil, drought is a phenomenon characterized by wide spatial coverage and recurrence in the country's semiarid region (SAB). Approximately 28 million people live in this region, including most of the poorest population in Brazil. The lack of access to water resources and recurrent droughts have affected the lives of the region's population for centuries, causing, among other things, malnutrition, migration, and premature deaths(OBERMAIER, 2011). Water security, defined as the ability to ensure the availability of water in the quantity and quality required to meet the needs of the human population and ecosystem(UNESCO, 2012), is at risk in the region(MARENGO et al., 2017).

The SAB contains more than half of the country's family-based rural establishments (SANTOS et al., 2015). More than $80 \%$ of the family farming establishments in the region are small farmers who practice subsistence agriculture in a rainfed system (IBGE, 2009). Due mainly to the high spatial and temporal variability of rainfall, the subsistence agriculture and extensive livestock farming practiced in this region are also variables that contribute to the configuration of the risk. In addition, the gap in efficient water storage systemswhich are almost always concentrated in the hands of the fewfurther intensifies the social impacts (MARENGO, 2008).

Between 2012 and 2017, the SAB was strongly impacted by a prolonged drought, already defined as the most intense "event" of the last 30 years (BRITO et al., 2017, CUNHA et al., 2018). The peculiarity of the extent, intensity, and duration of this drought event was amplified along with the impacts evidenced over the years, demonstrating how this extensive risk is configured over time. Considering the accumulated impacts between 2012 and 2016, about 1,100 municipalities were affected (about 20 million people affected per year), mainly in relation to the water supply and losses of the agroproductive systems. Considering only the payment of "crop guarantee" insurance, as one of the policies used to mitigate risk by increasing the capacity of producers to deal with the situation, the drought created a loss of almost $\mathrm{R} \$ 5$ billion (SAF/MAPA, 2017).

Regarding emergency actions directed at the water supply, the federal government continues to implement the "carro-pipa" operation, which is a public policy instrument that has been in force since 2005. This program provides emergency drinking water to the population impacted by drought. Between 2012 and 2016, about R\$5.6 billion was spent on water distribution through the "carro-pipa" operation (COTER, 2017). Such records corroborate the historical data, showing that drought is the type of natural hazard that triggers the greatest economic losses (CEPED, 2012); that is, it reveals vulnerabilities and leads to a disaster as it proceeds. 
As an aggravating factor, the $S A B$ is the main region of Brazil with areas susceptible to desertification, defined as soil degradation in arid, semiarid, and dry sub-humid areas, resulting from several factors. According to the latest CGEE survey (2016), heavily degraded areas in the desertification process amount to almost $70,000 \mathrm{~km}^{2}$ (about $5 \%$ of Northeast region of Brazil-NEB). Thus, these peculiarities of the $S A B$ in relation to the other regions of Brazil corroborate that the impacts of droughts present different intensities and vary geographically (SAUSEN e LACRUZ, 2015).

In recent years, the scientific knowledge related to the identification of areas affected by drought, as well as its evolution, has advanced significantly. Many studies have presented the results of spatiotemporal evaluations of the drought pattern, mainly considering biophysical indicators of the hazard, as well as the impacts associated with the hydrological deficit of the SAB (MARENGO e BERNASCONI, 2015, MARGULIS et al., 2010; CUNHA et al, 2017; MMA, 2017; BRITO et al, 2017; CUNHA et al., 2018).

On the other hand, few studies have considered the socioeconomic aspects related to droughts in the construction of a model of a disaster risk warning system (DRWS) related to this type of hazard, as already emphasized by Lindoso et al. $(2011,2014)$ andDebortoli et al. (2017).

The goal of this article is to present the state of the art of issues related to drought risk in Brazil and the current challenges for the consolidation of a drought-related DRWS. An integrated risk analysis is conducted that considers the spatial-temporal pattern of natural hazards, vulnerabilities, capabilities, and mitigation policies. Finally, a proposal is presented for a structure of responsibility attribution among the national institutions involved in this theme in order to guide their risk mitigation actions.

\section{CONCEPTS AND INDICATORS IN INTEGRATED RISK ANALYSIS}

Disaster risk is defined by the relationship between hazard(s), vulnerability(s), protection capacity(s), and public policies for the mitigation/reduction of risk. A drought is considered a disaster once the deficit directly affects human activities and outpaces the responsiveness of the social system. The natural phenomenon of drought alone does not cause a disaster, but when there are pre-existing conditions of social vulnerability (Mattedie Butzke, 2001; Kelman, 2018), revealed by a lack of effective disaster risk management, a disaster can occur.

A DRWS is defined as an integrated monitoring and forecasting system for hazards, disaster risk assessment, communication, and preparedness. It allows individuals, communities, governments, businesses, and others to take timely action to reduce disaster risks before dangerous events (UNISDR, 2017). Several international documents (UNISDR, 2006, 2017) and scientific studies (BASHER, 2006; MARCHEZINI et al., 2017b) carried out on warning systems have shown that their organization is structured around four fundamental axes: knowledge of risks, monitoring, communication, and responsiveness (Figure 1). 


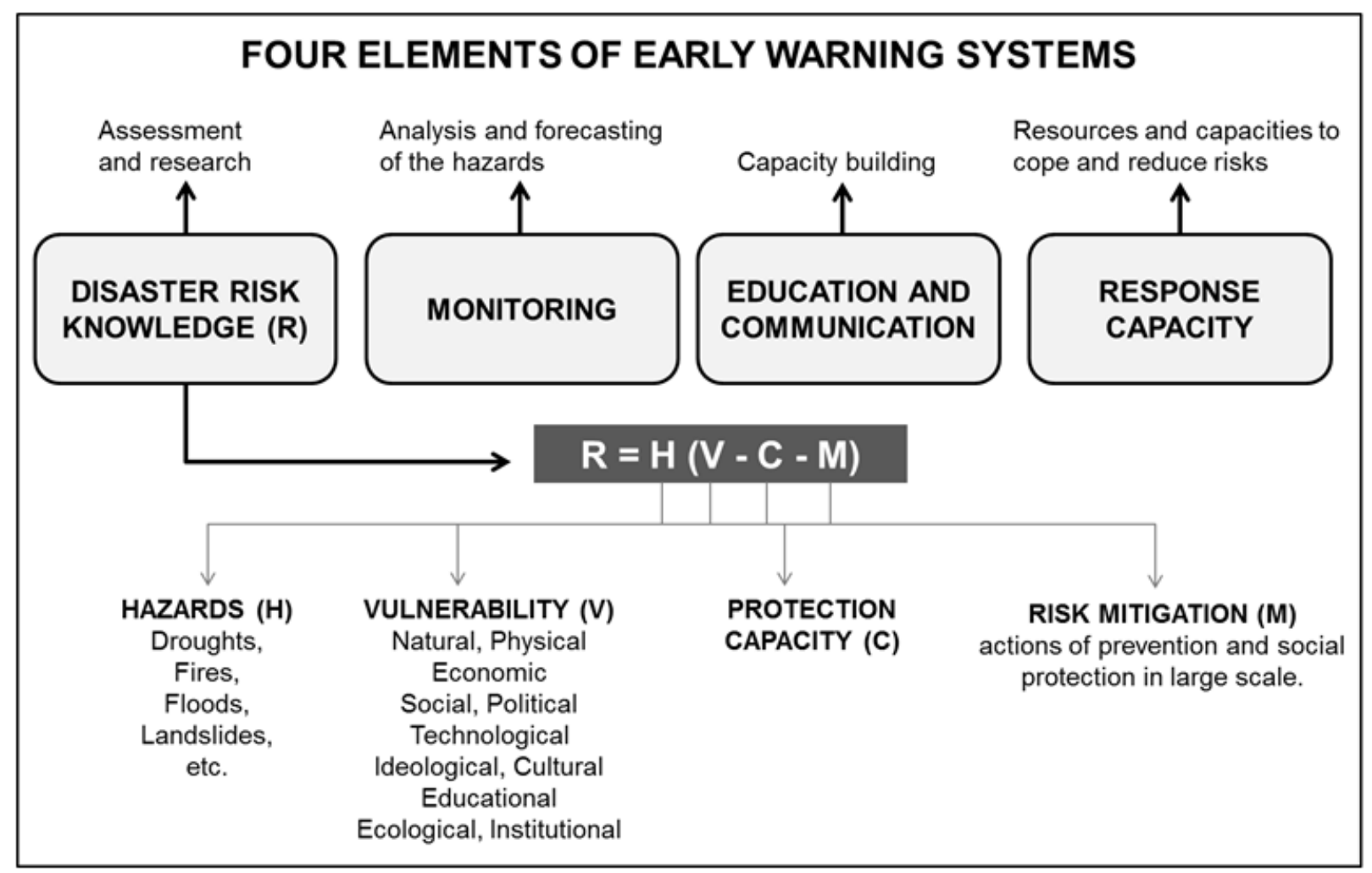

Figure 1: Elementsof a disaster risk warning system Source: Adapted fromMarchezini et al (2017a).

\subsection{KNOWLEDGE OF DROUGHT-RELATED DISASTER RISK}

Although there are definitions of different drought types in the literature, the absence of a precise and universally accepted definition increases the uncertainty about their characterization in terms of duration and degrees of severity (WILHITE, 2000). The difficulty is even greater when establishing universal indicators of drought for different regions, which is often necessary in continental countries such as Brazil. In these cases, the definitions of thresholds for the declaration of a drought situation are often arbitrary.

According to Wilhite (2000), the definitions of drought should be regionalized in terms of their impacts. In this context, the definition of drought should be related to its duration and the impacts caused. Generally, droughts are classified as meteorological, agricultural, hydrological, and socioeconomic (Figure 2).

A meteorological drought, the first to be perceived, was defined by Wilhite (2000) as the result of a precipitation deficit; that is, when the value of the accumulated rainfall in a period and in an area is significantly below the expected climatological value. Thus, the definition of a meteorological drought should be intrinsic to the region of occurrence, since atmospheric conditions that result in a precipitation deficiency are dependent on the climatic pattern inherent to the region.

In summary, it can be said that a meteorological drought is only indicative of a deficiency in precipitation, whereas agricultural and hydrological droughts are the physical manifestations of a meteorological drought (BOKEN et al, 2005).

An agricultural drought is the result of a water deficiency in the soil and consequent water stress to the plants, causing a reduction in biomass production. In general, agriculture is the first sector to be affected by drought, since soil moisture is the first component of the hydrological system to be affected. An agricultural drought is considered to be the most complex typology, since the associated impacts depend on their magnitude, duration, and timing, as well as the responses of soil, vegetation, and different types of crop to water stress. 
Regarding agricultural production, the impacts of droughts are directly associated with the phase in which the water deficit occurs (NAGARAJAN, 2009). For example, if the water deficit occurs during the flowering and grain filling stages of a crop, plant development may be affected, leading to a reduced grain yield. In the $S A B$, this aspect is very evident among the main rainfed crops: maize, cassava, and beans. Cassava is the most resistant because it is particularly sensitive to a water deficit after planting. Beans occupy an intermediate position, since besides germination, their flowering is dependent on favorable water conditions. Maize is the most vulnerable to the semiarid climate, with several phases of the cycle being very sensitive to a water deficit (LINDOSO et al., 2018).

Hydrological droughts are related to a reduction in the average levels of water in surface and subterranean reservoirs for a certain period of time; they vary in scale from months to years. A hydrological drought is the slowest in relation to meteorological and agricultural droughts. More time is needed to observe the long-term effects of a precipitation deficit on the components of hydrological systems (reservoirs, groundwater, etc.).

In the same way, the impacts are also out of step compared to other economic and more complex sectors to be measured (WILHITE, 2000), since water is used for different purposes (human supply, energy production, irrigation, etc.). A hydrological drought may persist for years, even after rainfall conditions normalize.

Finally, a socioeconomic drought is related to the impact of a drought on human activities, including direct and indirect impacts on agricultural production, the water available for human consumption, energy generation, and other economic activities (MAIA et al., 2015). The definition of a socioeconomic drought must connect issues related to supply and demand with the elements of meteorological, agricultural, and hydrological droughts in order to show the relationship between droughts and human activities (WILHITE, 2000). Figure 2 shows the interrelationships between the types of drought and the temporal aspects of the processes.

By definition, the disaster risks related to droughts for a specific region are a product of the interactions between exposure to the natural hazard (water deficit) and socioeconomic and environmental vulnerabilities associated with the event (Figure 3). According to the United Nations International Strategy for Disaster Reduction (UNISDR, 2017), vulnerabilities are conditions determined by physical, social, economic, and environmental factors or processes that increase the susceptibility of individuals, communities, goods, or systems to the impacts of hazards. Thus, drought risk management requires an integrated understanding of these two components in time and space. 


\section{Natural Climate Variability}

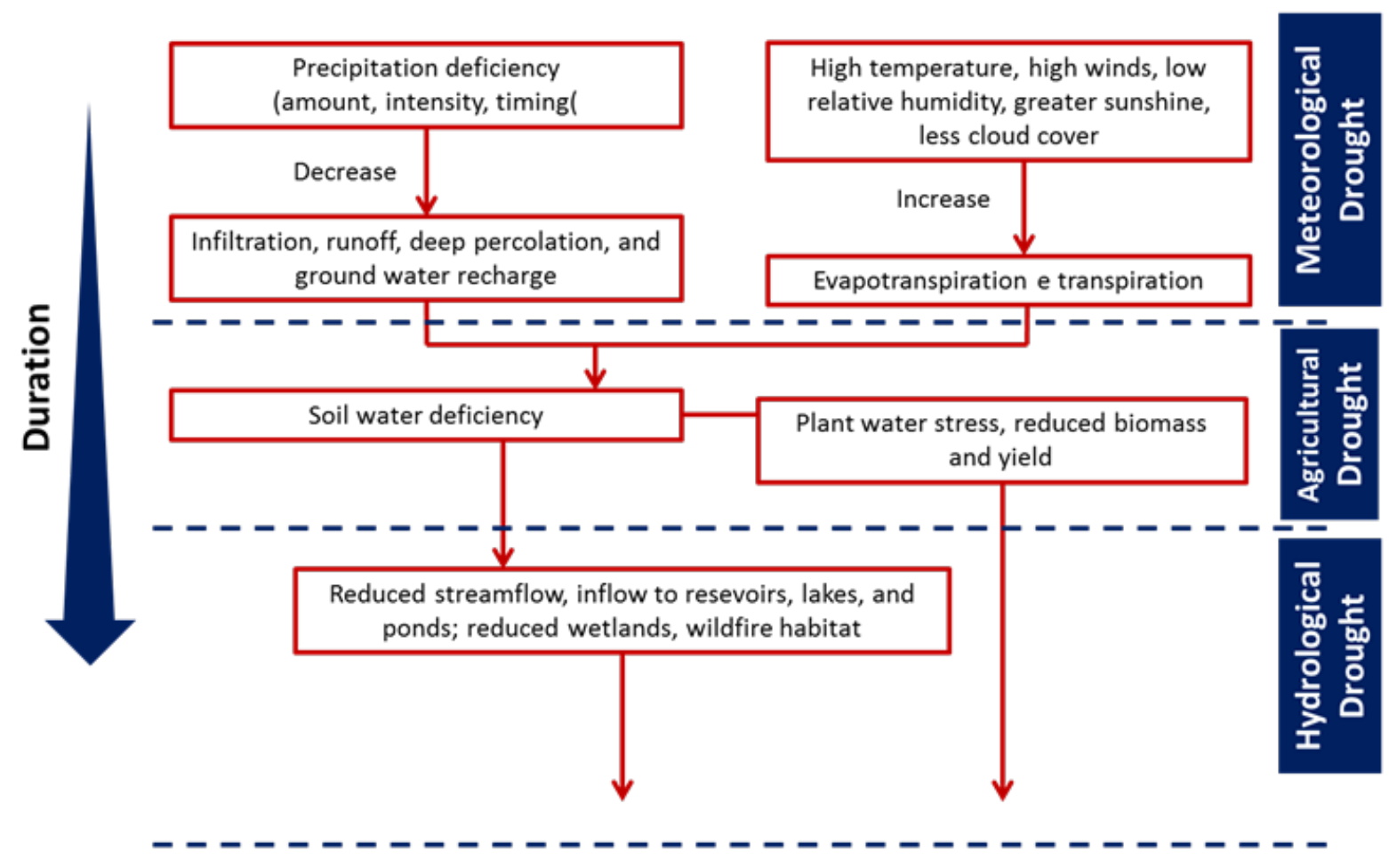

SOCIOECONOMIC AND ENVIROMENTAL IMPACTS

Figure 2 - Relationship between types of droughts and duration of processes. Source: Adapted from Wilhite, 2000.

Since drought perceptions vary geographically, and there are still divergences in the scientific and political environments regarding their characteristics, lacking or insufficient knowledge of the risks can lead to a delay in the response time and hamper the development of strategies for risk management associated with droughts. Thus, understanding the dimensions of vulnerability to droughts and considering the interdependent relationships between them are important factors in reaching a minimum consensus on definitions and understanding them from the point of view of risk management (WILHITE, 2000; BRENES et al., 2017).

From this first step, it is possible to establish a DRWS with different levels of warning that, in turn, imply actions concerning each level, carried out by a specific set of institutions that have attributions in that system. Regarding drought vulnerability, in the literature there is a set of studies that sought to identify it from both quantitative and qualitative points of view (HUMMEL et al., 2016; ALMEIDA, 2016; LINDOSO et al., 2018; LINDOSO et al., 2014).

However, there is a need to combine these vulnerability studies with the analysis of the hazards, in order to compose a drought-related disaster risk index or even different scenarios that may include different levels of warning. The definitions of these criteria may support monitoring in order to subsidize actions to minimize impacts.

\subsection{MONITORING OF DROUGHT-RELATED DISASTER RISK}

In addition to knowledge of risks, monitoring and warning actions are important for planning and mitigation actions (Figure 3). Risk monitoring includes activities to collect data and information to identify possible hazards and situations of imminent risk, with the purpose of subsidizing the issuance of early warnings of extreme events and recommending actions to reduce impacts. 
Drought risk monitoring aims to determine the nature and extent of the risk by analyzing the potential hazard and associated vulnerable conditions that could lead to impacts on society, livelihoods, and the environment on which society depends (UNISDR, 2017).

In general, drought indexes are developed for simplification, quantification, analysis, and communication. They allow an understanding of the phenomenon under study and make possible the simplification of complex phenomena, quantification, and information communication. Several methods and indices have been developed for the assessment and quantification of drought hazards considering different cause and response variables. The calculation of these indices requires different variables and methodologies, so it is therefore necessary to define which ones to use depending on the availability of input data, the spatial resolution, and the type of drought to be investigated. In the literature, it is possible to find a variety of drought indexes, including meteorological, hydrological, those based on data collected by sensors onboard satellites, outputs of water balance models (soil moisture), and others, used for the quantification and evaluation of drought impacts.

Drought events can be characterized in terms of their intensity, duration, and spatial coverage. The intensity refers to the degree of rainfall deficiency and/or the severity of the associated impacts. In this case, indexes based on precipitation data, such as the Standardized Precipitation Index (SPI, MCKEE et al.,1993) and the Palmer Drought Severity Index (PDSI, PALMER, 1968), are the most often employed. However, it is necessary to define the thresholds for the identification of the beginning and end of the drought event. For this, it is essential that studies are conducted to correlate the different drought intensities and their impacts (knowledge of risk). The duration of a drought is a second essential feature for monitoring, since the impacts are also associated with the period in which the precipitation deficit occurs. Finally, the characteristics related to the extension of the areas affected by the drought are of equal importance, especially in the context of the planning of actions to prepare for and mitigate the impacts, as emphasized by Wilhite (2000). In the spatial evaluation of droughts, information from remote sensors is often used (vegetation condition).

Such information is useful and appropriate for agricultural drought monitoring in large regions, such as the $\mathrm{SAB}$, and may provide indirect information on the variability of water availability for biomass production and vegetation conditions in general (CUNHA et al., 2015; ANDERSON et al., 2016).

From the physical variables (precipitation, temperature, vegetation condition, soil moisture, etc.) it is possible to develop multiple indicators for hazard assessment. Considering that no indicator used alone is enough to represent or measure the complex interrelationships between the various components of the hydrological cycle, as well as the associated impacts, within the scope of a large-scale risk monitoring system, it is necessary that a set of efficient indicators calibrated and validated is available. From the use of multiple indicators, it is possible to identify convergences of evidence of drought conditions, which is essential for greater reliability in decision making.

In view of its complexity and multidisciplinary, the hazard monitoring step needs to be articulated to include the participation of different actors from meteorological, hydrological, and agricultural agencies.

In the context of vulnerability and exposure, risk monitoring should also include social, economic, and environmental dimensions, as well as the ability to respond to different scenarios of possible risks. In this scope, it is important to consider information related to productivity losses (Secretariat of Family Agriculture and Cooperativism - SAFC, National Company of Supplying - Conab), local vulnerabilities (Special Secretariat for Social Development of the Ministry of Citizenship - SEDS/ MC, Agricultural Secretariats and "Companies of Technical Assistance and Rural Extension, ONGs, Environmental Ministry - MMA, etc.), and the scope of actions related to protection and mitigation capacities (SEDS, SFC, NGOs, etc.).

In the context of agricultural droughts, in addition to the hazard variables, the risk may also include i) the percentage of rainfed agriculture establishments; ii) the existence of perennial water bodies (such as rivers and large reservoirs); iii) the degree of sensitivity of productivity to the environment; 
iv) economic dependence on agroproductive activities; and others. On the other hand, information such as planted and harvested areas, as well as average yield, are useful indicators for assessing drought-related impacts. About livestock production, data on the spatial distribution and size of herds, for example, can be included.

Regarding hydrological droughts, relevant indicators are access to cisterns, the presence of reservoirs in municipalities or adjacent municipalities, and the percentage of the rural population covered by the "carro-pipa" operation. Today, in the SAB, the combination of the "Water for All Program" and the "carro-pipa" operation constitutes an important rural water supply system.

Other relevant indicators for risk monitoring, in relation to the socioeconomic aspect, are i) the size of the rural population, ii) the percentage of the municipal gross domestic product dependent on agriculture, and iii) the population engaged in agricultural activities. Through these indicators, a better understanding of demographic sensitivity is possible.

Due to the spatial and temporal availability of the necessary data for risk monitoring, it is essential to define the municipal level as the unit of exposure. From this definition, the input data for the monitoring system must be absolute and standardized in order to aggregate/match data from different sources.

By integrating this different information with that of a physical nature associated with drought events, it is possible to identify the most vulnerable groups and sectors during a drought event and, from this, direct investments in public actions to mitigate the effects of a drought in advance.

\subsubsection{DROUGHT MONITORING SYSTEMS IN BRAZIL}

Regarding hazard monitoring as subsidized by the Brazilian federal government through the implementation of drought-mitigating actions, in 2013, the Ministry of National Integration established partnerships with the National Water Agency (ANA), Foundation for Meteorology and Hydrology (FUNCEME), and other institutions for the implementation of a drought (hazard) monitoring system for northeast Brazil, based on the methodology adopted by the United States Drought Monitor developed by the University of Nebraska (MARTINS et al., 2015).

Named the "Northeast Drought Monitor," this system came online in early 2016. It presents a monthly map that describes the current drought conditions. The Drought Monitor is based on three indicators, two of which are meteorological (covering both the short and long terms) and one of which is hydrological (covering the short term) (DE NYS et al., 2016).

In 2013, due to the extent and severity of the drought that started in 2012 in northeast Brazil, the Brazilian federal government asked the Brazilian National Centre for Monitoring and Early Warning of Natural Disasters (CEMADEN) to support the identification of municipalities affected by drought, with the aim of subsidizing emergency support for the municipalities. Since then, CEMADEN has been operationally monitoring the northeastern region and other regions of Brazil.

This Drought Monitoring System implemented by this federal agency considers several drought indices, among them the SPI, soil moisture from CEMADEN's observational network, evapotranspiration, drought indexes based on remote sensing (Vegetation Water Supply Index and Vegetation Health Index), and flow rates from different institutions.

As a research center of the Ministry of Science, Technology, Innovation and Communications (MCTIC), CEMADEN, in addition to conducting drought and impact monitoring, also aims to generate scientific and technological knowledge on hazards, processes, and vulnerabilities associated with droughts and their impacts, in order to assist society and decision makers. Thus, CEMADEN has developed scientific knowledge and new methodologies that can contribute to the implementation of a drought-related DRWSin Brazil. 


\subsection{RISK COMMUNICATION}

Risk communication refers to actions aimed at informing and notifying various social actors, such as public agents at different levels of government and sectors (emergency, health, transport, etc.), exposed communities, and voluntary organizations on a given space scale (country, state, region, municipality, and place) and time scale (time of year, month(s), day(s), and time of day) about possible risks (hazards and vulnerabilities).

In general, it is necessary to build and/or improve the mechanisms for effective communication between these actors in order to improve the drought disaster risk management system. In addition, as emphasized by Wilhite et al. (2014), the integration of science and policy during the strategic planning process is also essential for defining priority research and the leveling of current knowledge.

The difficult challenge of creating a collaborative framework and implementing adaptive strategies at scales ranging from local communities to river basins encompasses several states and requires a wide range of scientific policy responses.

\subsection{RESPONSE CAPACITY AND MITIGATING ACTIONS}

In the axis related to the response capacity (Figure 3 ), the forms of local organization and the strategies adopted to respond to extreme events and risks in the territory are included. In general, response capabilities are associated with economic, social, cultural, and institutional conditions related to dealing with hazards.

Since the 1950s, the Brazilian federal government has expended efforts to subsidize the formulation of strategies to prevent and mitigate the effects of drought (GUTIERREZ et al, 2014). In the context of prevention, the main actions in the last two decades have involved major water infrastructure works (transposition of the São Francisco River, construction of canals, reservoirs, etc.) combined with decentralization of access to water through the construction of small reservoirs for production and human supply at the establishment scale.

In 2003, the federal government created the "1 Million Cisterns Program" (P1MC), which was later complemented by the "Water for All Program" in 2011. The program had as its goal the construction of one million cisterns to collect rainwater as a form of water supply during periods of drought in the SAB (LUNA, 2011). The P1MC was innovative in seeking to decentralize solutions and reduce spaces of clientelist mediation, which has historically permeated governmental actions in the region (DIAS et al., 2016). On the other hand, it is important to note that, unlike the P1MC, the implementation of other public actions and policies is generally guided by the geographical delimitation of the $S A B$, which is formulated based solely on climate variables (SUDENE, 2018).

Among the main actions and public policies for risk mitigation that focus on the SAB as a priority and often exclusive area of governmental action (MI, 2017), the following stand out:

- BNB bank financing lines (Northeastern Constitutional Financing Fund resources - differentiated treatment for the $S A B$ );

- Land Credit;

- Agricultural Insurance for the SAB;

- National Program for the Strengthening of Family Agriculture;

- Brazil Without Extreme Poverty;

- Food Acquisition Program;

- Brazilian National School Food Program;

- Emergency program of drinking water supply ("carro-pipa" operation); 
- Freshwater Program;

- Smallholder Farming (ATER/Rural Environmental Registry);

- National Policy on Technical Assistance and Rural Extension - Support for technological innovation projects of smallholder farming in the SAB;

- Sustainable Agriculture and Livestock Program;

- Research and Innovation Program for Agriculture;

- Water for All Program;

- P1MC

- "1 terra 2 águas" Program (P1 +2)

- Combating Desertification and Mitigating the Effects of Drought (Law 13.153, of July 30, 2015);

- Water Reuse in the Brazilian Semiarid Project;

- San Francisco Basin Revitalization Program;

- Irrigationperimeters; and

- Project for family agricultural systems resilient to extreme environmental events in the context of the Brazilian SAB: alternatives for coping with desertification and climate change processes (INSA and Articulation in the Brazilian Semiarid - ASA).

The last major drought (2012-2017) was a testament to the fact that disasters associated with droughts are not limited only to the geographical region of the SAB. Municipalities located outside this delimitation were also severely affected (CUNHA et al., 2015; CUNHA et al., 2018). Thus, mitigation and preparedness actions should be subsidized by mapping the risk areas/sub-regions, which should include physical aspectsof drought (hazard), as well as aspects of vulnerability to the effects of drought.

In addition, despite the implementation of different public policies, major efforts are still focused on mitigating the impacts, such as providing emergency responses to a given drought situation (water distribution, food, income transfer, etc.). Income transfer programs have improved the indicators of health and quality of life of the populations in many regions (PIRES, 2014), but vulnerability to drought impacts is still high. The food security1 numbers of the rural NEB population evidence this.

According to the Supplementary Food Security Survey of 2013 (IBGE, 2013), about 50\% of the rural population of the NEB is food insecure. For Lemos et al. (2016), although the "Bolsa Família" program has also contributed to raising the income of the poorest people, it has not been enough to avoid the risk of food insecurity during drought events, so families are making little progress in reducing their vulnerability.

In order for the population's vulnerability to the effects of drought to reach tolerable levels, it is necessary to build endogenous territorial development strategies so that programs to combat poverty are not limited to income transfer, but incorporate policies for development and the promotion of sustainability, changing the structure of social vulnerability, restoring degraded ecosystems, and offering income generation opportunities adapted to the local environmental context.

In this context, a DRWS, as advocated in the present work, constitutes an important tool for drought risk management. Risk management should address the current hazards and vulnerabilities and strategies to reduce them, but also consider forward-looking risk management to identify future scenarios and prevent risk from being created and/or intensified, with precautionary measures being taken accordingly. With a view to evaluating the right corrective and prospective actions under discussion and formulating planning proposals, it is fundamental to identify the matrix of 
responsibility of the institutions related to risk governance, providing for instances of participation so that society can express/contribute to formulating and implementing strategies.

\section{MATRIX OF RESPONSIBILITIES FOR A DROUGHT-RELATED DRWS}

Table 1 presents a first attempt at assigning responsibilities to improve the operation of a droughtrelated DRWS. As it is a first survey, many other research, teaching, and technical development institutions must still be incorporated.

With regard to the assignment of responsibilities for risk knowledge, as well as for the other stages, the complexity of dealing with risks demands a multidisciplinary (several sciences), interdisciplinary (between sciences), transdisciplinary (science, society, and public institutions), interinstitutional (between different related institutions), and intersectoral (e.g., education, health, and environment) arrangement. Risk knowledge is improved through technical-scientific and traditional knowledge dialogues and advances in various efforts toward a common challenge: reducing socioeconomic and environmental losses in the face of increasingly frequent, intense, and long-lasting disasters.

In relation to the institutions that carry out actions in this first axis of the DRWS, we can mention those dedicated to understanding the characteristics of the hazard, for example, state meteorological centers; universities; the National Meteorological Institute of the Ministry of Agriculture, Livestock and Supply (INMET/MAPA); the National Institute of Space Research (INPE); the ANA; CEMADEN, etc. Also, for the vulnerability, capacities, and mitigation policies of drought impacts, there is CEMADEN, the National Institute of Semiarid (INSA), the Brazilian Agricultural Research Corporation (EMBRAPA), Secretariat of Family Agriculture and Cooperativism, the Superintendency for the Development of the Northeast (SUDENE), Conab, universities, NGOs, etc. Such institutions act to provide relevant data and information on the generation of knowledge, on both hazards and vulnerabilities. 


\section{DROUGHT-RELATED DISASTER RISK}

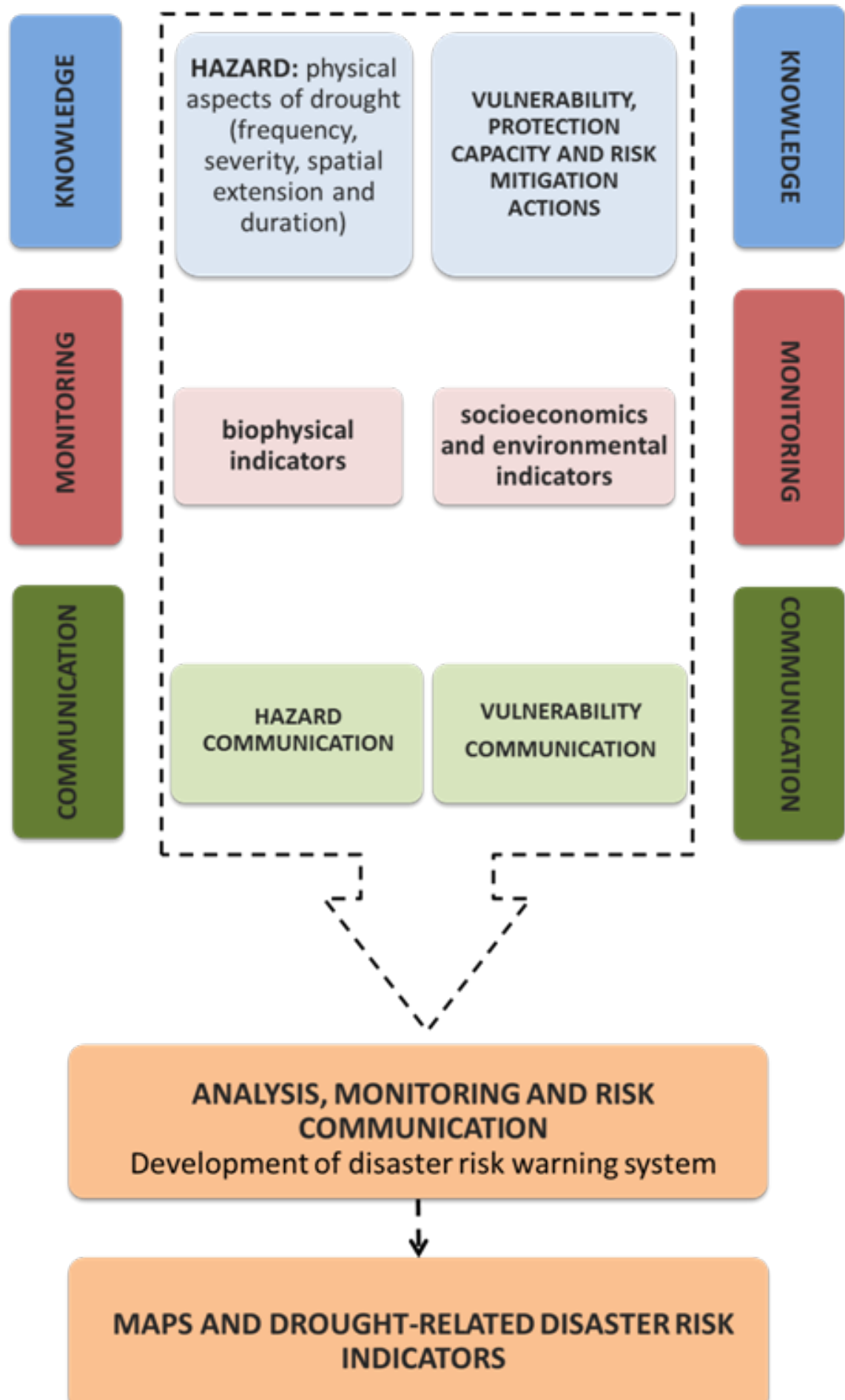

Figure 3 - Drought-Related Disaster Risk Warning System. Source: Prepared by the authors. 
The challenge that remains is generating knowledge about the drought-related disaster risk. If the first axis of a warning system calls for joint efforts on its improvement and integration, governance mechanisms still need to be improved with respect to the forms of monitoring, risk communication, and responsiveness.

Table 1 - Matrix of responsibilities for a drought-related DRWS.

\begin{tabular}{|c|c|c|c|c|c|}
\hline \multirow{2}{*}{$\begin{array}{l}\text { INSTITUTION/ } \\
\text { RESPONSABILITITES }\end{array}$} & \multicolumn{2}{|c|}{ RISK KNOWLEDGE } & \multirow{2}{*}{$\begin{array}{l}\text { MONITORING AND } \\
\text { WARNING }\end{array}$} & \multirow{2}{*}{$\begin{array}{l}\text { EDUCATION AND } \\
\text { COMMUNICATION }\end{array}$} & \multirow{2}{*}{$\begin{array}{l}\text { RESPONSE } \\
\text { CAPACITY }\end{array}$} \\
\hline & hazards & vulnerabilities & & & \\
\hline ANA & $x$ & & $x$ & & \\
\hline Cemaden & $x$ & $x$ & $x$ & $x$ & \\
\hline $\begin{array}{l}\text { State meteorological } \\
\text { centers }\end{array}$ & $x$ & & $x$ & & \\
\hline Conab & & $x$ & & & \\
\hline Emater/states & & $x$ & & $x$ & $x$ \\
\hline Embrapa & & $x$ & & $x$ & \\
\hline Public institutions & & & & $x$ & $x$ \\
\hline $\begin{array}{l}\text { Brazilian Institute of } \\
\text { Geography and Statistics - } \\
\text { IBGE }\end{array}$ & & $x$ & & & \\
\hline Inpe & $x$ & & $\mathrm{x}$ & & \\
\hline Inmet & $x$ & & $x$ & & \\
\hline Insa & & $x$ & & $x$ & $x$ \\
\hline Seds & & $x$ & & $x$ & $x$ \\
\hline SAFC & & $x$ & & & $x$ \\
\hline $\begin{array}{l}\text { National Secretariat for Civil } \\
\text { Protection and Defense - } \\
\text { Sedec }\end{array}$ & & & & $x$ & $\mathrm{x}$ \\
\hline Universities & $x$ & $x$ & & $x$ & \\
\hline Sudene & & $x$ & & $x$ & $x$ \\
\hline
\end{tabular}

Source: Prepared by the authors.

\section{CONCLUSION AND RECOMENDATIONS}

The human and agroproductive impacts experienced during the period of intense rainfall between 2012 and 2017 in the whole of northeastern Brazil again raised questions related to the preparation for droughts. Since the mid-1990s, policies, programs, and actions that address vulnerability have been implemented, but they have only advanced in a specific way in some specific areas, especially in the area of water security.

The political portfolio, even though it refers to droughts, is still organized in silos, without an organic articulation capable of promoting a structural change in vulnerability. The mitigation policies for drought impacts with greater relevance in terms of coverage are still those of an emergency nature, such as "crop guarantee" insurance and the "carro-pipa" operation, or those related to the transfer of income, such as the family grant, pensions, and benefits of provision. The intrinsic local structure of vulnerability has changed little in the last century, except for pilot projects or timely contexts. The exception is P1MC, which has significantly and structurally altered access to water in many areas facing water insecurity, especially when associated with the "carro-pipa" operation.

In addition, another aggravating factor is the delimitation of the SAB as a focus for the application of public policies directed toward the drought: only the municipalities in the SAB benefit. However, recent 
studies have shown that the impacts of the 2012-2017 drought extended beyond this boundary, which means that the drought patterns previously seen as restricted to the SAB may become frequent in adjacent areas. The DRWSs are important mechanisms for the creation of public perceptions about these scenarios in order to allow for their prospective management.

In recent decades, possibly related to global warming, droughts have increased in frequency and intensity in several countries around the world. Brazil is no exception. The country already has a history of severe impacts associated with droughts and it is probable that in the future these events will be more intense and frequent (MARENGO, 2008). In order to prepare for such a situation, it is necessary to create an integrated drought risk warning system in Brazil of a transdisciplinary and interinstitutional nature, and above all centered on people (MARCHEZINI et al, 2017b), in order to guide the risk management of droughts in Brazil.

In the specialized literature, it is already agreed that the risks associated with droughts for a specific region are a product of the interaction between exposure to the natural hazard (rainfall deficit) and socioeconomic and environmental vulnerabilities to this event. Risk management for droughts requires the integrated understanding of these two components in time and space. Thus, the first step toward consolidating a drought-related DRWS should be the conceptual leveling of "risk associated with disasters." The lack of this conceptual leveling today is one of the triggers of institutional competitiveness, pulverization, and overlapping of existing actions, be they technical, scientific, or political.

A next step in reducing this institutional vulnerability would be to rely on an array of responsibilities to guide risk awareness, monitoring and warning, education/communication, and responsiveness actions. As already explained, this system presupposes a synergistic composition of all of the institutions involved for its full functioning.

As already mentioned, in relation to the monitoring of the physical aspects of drought, Brazil has made significant progress, evidenced by the two monitoring systems developed (Northeast Drought Monitor ANA and Drought Monitoring and Impacts System -CEMADEN) for the various institutions dedicated to this topic, who often act without articulation. In this sense, it is necessary to create mechanisms for the integration and articulation of technical, scientific, and popular knowledge of the various dimensions of risk.

Equivalent progress has been made in monitoring socio-environmental vulnerability. The legitimacy and relevance of these systems depend on their ability to dialogue with the various institutions and actions already dedicated to and formulated for increasing the resilience of society to drought. While it would inform decision making on mitigation policies, the monitoring system could benefit from knowledge about the occurrence of droughts, the potential effects and vulnerabilities of potentially affected people, and economic activities. This would lead, first, to a system of dialectic monitoring between science and decision making based on the integration of socioeconomic, environmental, and climatic indicators, which, besides informing, could serve as a framework to explain and promote the transversality of vulnerability management as a multidimensional context.

This article presented the conceptual elements necessary for a drought-related DRWS in Brazil. However, in order to implement such a system, it is necessary for institutions to take responsibility for risk governance according to their competencies. Also, it is just as important for there to be a common perception that there is an adaptive deficit to vulnerability present in the context of climate change.

\section{FOOTNOTE}

${ }^{1}$ Law 11.346/2006: Food and Nutrition Security includes the realization of the universal right to regular and permanent access to quality food in sufficient quantity, without compromising access to other essential needs, based on health-promoting food practices that respect cultural diversity and are environmentally, culturally, economically and socially sustainable. 


\section{REFERENCES}

ALMEIDA, L.Q.; WELLE, T.; BIRKMANN, J. Disaster risk indicators in Brazil: a proposal based on the world risk index. International Journal of Disaster Risk Reduction, v. 17, p. 251-272,2016.

ANDERSON, B. et al. Drought Response, Water Resources Program. Olympia, WA: Washington State Department of Ecology. 2016.

BASHER, R. Global early warning systems for natural hazards: systematic and people-centred, Philosophical Transactions. Series A, Mathematical, Physical, and Engineering Sciences, v. 364, n. 1845, p. 2167-2182, 2006.

BOKEN, V.K.; CRACKNELL, A.P.; HEATHCOTE, R.L. Monitoring and predicting agricultural drought: a global study. Oxford University Press, Auckland.2005.

BRASIL. Ministério da Integração Nacional. Relatório Final: Grupo de Trabalho para a delimitação do Semiárido, 2017. Disponível em: <http://www.integracao.gov.br/documents>.

BRASIL. Ministério do Meio Ambiente. Índice de vulnerabilidade aos desastres naturais relacionados às secas no contexto da mudança do clima: sumário executivo / Ministério do Meio Ambiente, Ministério da Integração Nacional, WWF-Brasil. - Brasília, DF, 2017.

BRASIL. Secretaria Especial de Agricultura Familiar e do Desenvolvimento Agrário. Disponível em: <http://www. mda.gov.br>. Acesso em: 07 mar. 2017.

BRENES, A. El concepto de la sequía en el marco de la gestión del riesgo de desastre. In:Reduction of Vulnerability to Disasters: from knowledge to action.MARCHEZINI, V. et al. (Ed.), p.143-164. São Carlos: Rima Editora, 2017.

BRITO, S.S.B. et al. Frequency, duration and severity of drought in the Brazilian Semiarid. InternationalJournalofClimatology, v. 38, n. 2, p. 517-529, 2017.

CENTRO DE GESTÃO E ESTUDOS ESTRATÉGICOS. Desertificação, degradação da terra e secas no Brasil. Brasília, DF: 2016. 252 p.

CENTRO UNIVERSITÁRIO DE ESTUDOS E PESQUISAS SOBRE DESASTRES. Atlas brasileiro de desastres naturais 1991 a 2012: volume Brasil. 2013.

COMANDO DE OPERAÇÕES TERRESTRES. Disponível em: <http://www.coter.eb.mil.br/index.php/div-coor-civmil>. 2017.

CUNHA, A. P. M. et al. Monitoring vegetative drought dynamics in the Brazilian semiarid region. Agricultural and Forest Meteorology, v. 214-214, p. 494-505, 2015.

CUNHA, A. P. M. A. et al. Avaliação de indicador para o monitoramento dos impactos da seca em áreas de pastagens no semiárido do Brasil. Revista Brasileira de Cartografia. v. 69, n. 1, 2017.

CUNHA, A.P.M.A. et al. Changes in the spatial-temporal patterns of droughts in the Brazilian Northeast. In Press, Atmospheric Science Letters. 2018.

DEBORTOLI, N. S. et al. An index of Brazil's vulnerability to expected increases in natural flash flooding and landslide disasters in the context of climate change. Natural Hazards (Dordrecht), v. 85, p. 1-25, 2017.

DE NYS, E.; ENGLE, N. L.; MAGALHÃES, A. R. Secas no Brasil: política e gestão proativas. Brasília, DF: Centro de Gestão e Estudos Estratégicos - CGEE; Banco Mundial, 2016. 292 p.

DIAS, T.F. et al. Water Resources Management Coexistence and Conflict in Semiarid Brazil. Desenvolv. Quest.v. 14, p. 91-136, 2016.

GUTIERREZ, A. P. A. et al. Drought preparedness in Brazil. Weather and Climate Extremes. 2014. 
HUMMEL, B.M.L.; CUTTER, S.; EMRICH, C.T. Social Vulnerability to Natural Hazards in Brazil. InternationalJournalofDisaster Risk Science, v. 7, p. 111-122, 2016.

INSTITUTO BRASILEIRO DE GEOGRAFIA E ESTATÍSTICA. O censo agropecuário 2006 e a agricultura familiar no Brasil. MDA, Brasília, 2009.

INSTITUTO BRASILEIRO DE GEOGRAFIA E ESTATÍSTICA. Pesquisa nacional por amostra de domicílios: segurança alimentar. Rio de Janeiro: IBGE; 2013.

KELMAN, I. Lost for Words Amongst Disaster Risk Science Vocabulary? International Journal of Disaster Risk Science, v. 9, n. 3, p. 281-291, 2018.

LEMOS, M.C. et al. The relative relationship between generic and specific capacities in reducing drought vulnerability in households in NE, Brazil. Global Environmental Change, v. 39, p. 170-179, 2016.

LINDOSO, D. et al. Climate Change and Vulnerability to drought in the Semiarid: the case of smallholder farmers in the Brazilian northeast. In: MOTTA, S. et al. (Ed.). Climate change in Brazil: economic, social and regulatory aspects. Brasília: Ipea, p. 235-256, 2011.

LINDOSO, D. P. et al. Integrated assessment of smallholder farming's vulnerability to drought in the Brazilian Semiarid: a case study in Ceará. Climatic Change, v. 127, p. 93-99, 2014.

LINDOSO, D. et al. Harvesting Water for Living with Drought: insights from the Brazilian human coexistence with semi-aridity approach towards achieving the sustainable development goals. Sustainability, v. 10, p. $622,2018$.

LUNA, C. F. Avaliação do impacto do Programa Um Milhão de Cisternas Rurais (P1MC) na saúde: ocorrência de diarreia no Agreste Central de Pernambuco. 2011. 207 f. Tese (Doutorado em Saúde Pública) - Centro de Pesquisas Aggeu Magalhães, Recife, 2011.

MAIA, R.; VIVAS, E.; SERRALHEIRO, R. et al. Water Resour Manage. v. 29, p. 575, 2015.

MARCHEZINI, V. et al. Sistema de alerta de risco de desastres no Brasil: desafios à redução da vulnerabilidade institucional. In: MARCHEZINI, V. et al. (Org.). Reduction of vulnerability to disasters: from knowledge to action. São Carlos: Rima Editora, 2017a, v. 1, p. 287-310.

MARCHEZINI, V. et al. Participatory Early Warning Systems: youth, citizen science, and intergenerational dialogues on disaster risk reduction in Brazil. InternationalJournalofDisaster Risk Science, v. 8, p. 390-401, 2017 b.

MARENGO, J. A. Água e Mudanças Climáticas. Estudos Avançados, v. 22, p. 83-96, 2008.

MARENGO, J.A.; BERNASCONI, M. Regional differences in aridity/drought conditions over Northeast Brazil: present state and future projections. Climate Change,v. 129, p. 103-115, 2015.

MARENGO, J.A. et al. Climatic characteristics of the 2010-2016 drought in the semiarid Northeast Brazil region.In press. Anais da Academia Brasileira de Ciências. 2017.

MARGULIS, S. et al. (Ed.) Economia da mudança do clima no Brasil: custos e oportunidades. São Paulo: IBEP Gráfica, 2010.

MARTINS, E. S. P. R. Monitor de Secas do Nordeste: em busca de um novo paradigma para a gestão de secas. Série Água, v. 10. 2015.

MATTEDI, M. A.; BUTZKE, I. C. A relação entre o social e o natural nas abordagens de hazards e de desastres. Ambiente\&Sociedade. Ano IV, n. 9, 2001.

MCKEE, T. B.; DOESKEN, N. J.; KLEIST, J. The relationship of drought frequency and duration to time scales. In: Eighth Conference on Applied Climatology, Anaheim, CA. 1993.

NAGARAJAN, R. Drought Assessment.Springer, Dordrecht, Netherlands, 2009. 
OBERMAIER, M. Velhos e novos dilemas nos sertões: mudanças climáticas, vulnerabilidade e adaptação no semiárido brasileiro. Rio de Janeiro, 2011. Tese (Doutorado em Planejamento Energético) - Coppe, Universidade Federal do Rio de Janeiro. Rio de Janeiro, 2011.

PALMER, W.C. Keeping track of crop moisture conditions, nationwide: the new Crop Moisture Index. Weatherwise, v. 21 , p. $156-161,1968$.

PIRES, F. F. Child as family sponsor: an unforeseen effect of Programa Bolsa Família in northeastern Brazil. Childhood, v. 21, n. 1, p. 134-147, 2014.

SANTOS, D. P. A.; VIDAL, D. de L. Realidade territorial de unidades familiares no semiárido brasileiro. Tempo Social (USP. Impresso), v. 28, p. 55-83, 2015.

SAUSEN, T. M.; LACRUZ, M. S. P. Sensoriamento remoto para desastres.EditoraOficina de textos. 2015.

UNISDR. Developing early warning systems, a checklist: third international conference on early warning (EWC III), 27-29 Março de 2006, Bonn, Germany-UNISDR.

UNISDR. Drought Risk Reduction Framework and Practices: contributing to the implementation of the Hyogo. Framework for Action. United Nations secretariat of the International Strategy for Disaster Reduction (UNISDR), Geneva, Switzerland, 213 p. 2012.

UNISDR. Terminology on Disaster Risk Reduction. United Nations International Strategy for Disaster Reduction (UNISDR) Geneva, Switzerland, 2017.

UNISDR. Multi-hazard early warning systems: a checklist. First Multi-hazard Early Warning Conference, 22 to 23 May 2017 - Cancún, Mexico.

UNITED NATIONS EDUCATIONAL, SCIENTIFIC AND CULTURAL ORGANIZATION. International Hydrological Programme - IHP. 20th Session of the Intergovernmental Council. Paris, June 2012.

WILHITE, D. A. Drought as a natural hazard: concepts and definitions. In: Drought: a global assessment. DONALD, A. WILHITE, A. (Ed.). Routledge: New York, NY. 2000.

WILHITE, D. A.; SIVAKUMAR, M. V. K.; PULWARTY, R. S. Managing drought risk in a changing climate: the role of national drought policy. WeatherClimExtrem, v. 3, p. 4-13, 2014. 